\title{
The Effects of Differentiated Science Teaching According to the Grid Model
}

\author{
Serkan DEMiR ${ }^{1}$ \\ ${ }^{1} \mathrm{PhD}$, Beşiktaş Science and Art Center, Istanbul, Turkey
}

\begin{abstract}
The aim of this study is to determine the effect of science lesson activities prepared in accordance with the components and steps of the grid model on the creative thinking skills, problem-solving skills and attitudes of gifted students. In this study, pre-test and post-test design with the control group were utilized among the experimental designs. The study group consisted of 44 students (23 in the experimental group, 21 in the control group) in the 9-10 age group, who were identified as gifted students and who attend the same Science and Art Center support education program in Istanbul. The analysis revealed that the differentiated implementations of Science according to the Grid Model had a significant impact on the creative thinking and problem-solving skills and attitudes of gifted students. In this study, the "Problem Solving Inventory for Primary Education Children" developed by Serin, Bulut Serin and Saygll (2010), the "Attitude Scale towards the Science Course" created by Kenar and Balc1 (2012), and Torrance Creative Figural A booklet, one of the Thinking Tests, were used. Within the scope of the study, it has revealed that its applications differentiated according to the Grid Model have a significant effect on the creative thinking and problem-solving skills and attitudes of gifted students.
\end{abstract}

Keywords: Grid Model, Science Teaching, creative thinking, problem-solving skills and attitudes

\section{INTRODUCTION}

Studies that reveal the characteristics and skills of gifted and talented students in science were analyzed. According to the analysis, the characteristics and skills of gifted students were determined as being curious, interested in scientific problems, being willing to use scientific process skills, reading and following articles on scientific subjects, being interested in scientific projects or research, and showing interest in natural events (Callahan, 2017; Reis \& Hausand, 2008; Renzulli et al., 2002; Sumida, 2017).

Although gifted students have advanced mental comprehension, insight, abstract thinking and metacognitive skills compared to their peers with the above-mentioned features and skills, they cannot receive education with a curriculum suitable for science teaching. This situation is insufficient to reveal the potential of the students and to advance their potential. In addition, the situation negatively affects the interest, curiosity and motivation levels of students. The lack of a science program suitable for gifted and talented students also causes students not to be given the opportunity to experience high-level thinking skills and scientific process skills (Johnson, Boyce \& VanTassel-Baska, 2013; Karnes \& Riley, 2005).

Robinson, Shore, and Enersen (2007) stated in their study that science textbooks do not offer gifted and talented students the opportunity to research, and that science textbooks do not offer these students problem-solving activities in the field of science. As a result of the research conducted by Cross (2011) it was determined that gifted and talented students experience disappointment in science lessons who need to encounter applied activities, research and inquiry-based learning rather than memorization in science lessons.
When the relevant literature is examined, it is emphasized that the program to be applied in science education of gifted and talented students should include scientific inquiry activities in order to observe the gifted behaviors and develop their scientific thinking skills. (BiologicalScienceCurriculumStudy, 2006; Trna\&Trnova',2015). In addition, it has been stated that differentiated programs organized within the framework of scientific principles that require advanced thinking, complex processes and creative productivity in science education should be implemented (Cooper, Baum \& Neu, 2004; Gould, Weeks \& Evans, 2005; Meador, 2003; Tomlinson 2014).

VanTassel-Baska and Stambaugh (2006) argue that the program to be developed or implemented in order to meet the science education needs of gifted and talented students and to increase their interest in science should include certain components. VanTassel-Baska and Stambaugh define these components as (1) to understand scientific concepts (2) to develop a knowledge base in the field of science (3) to develop scientific research skills in a collaborative environment (4) to

\section{Corresponding Author e-mail: serkandemir4@gmail.com https://orcid.org/0000-0002-2331-9861}

How to cite this article:DEMIRS, (2021). The Effects of Differentiated Science Teaching According to the Grid Model. Pegem Journal of Education and Instruction, Vol. 11, No. 4, 2021, 148-159

Source of support: Nil

Conflict of interest: None.

DOI: $10.47750 /$ pegegog.11.04.14

Received: 16.05.2021

Accepted: 08.08.2021 Publication: 01.10.2021 
provide interdisciplinary connections (5) developing research and questioning skills for real life skills (6) improving scientific thinking skills. An important program differentiation model that contains these components in its structure is the Grid Model.

The Grid Model, which is especially used in the education of gifted and talented students, is also a model created to offer differentiated learning experiences for students studying in regular classes. When the details of the model are examined, it is seen that the model offers the opportunity for teachers who want to apply differentiated instruction in their classrooms. The model uses content, process and product components organized around a "theme". Teachers who choose to apply the Grid Model in their classroom should first determine a theme and then create the content, process and product dimensions suitable for the theme. After determining a theme that is related to a certain discipline, concretely stated, directed by the teacher and selected by the student, which offers the opportunity to do many activities, teachers should work on the dimensions of content, process and product in an order. When working on these elements, the following features should be considered.

Content: Content should include a range of discussion topics for the chosen theme, as well as problematic issues that must be addressed within the theme's context, topics that the students are interested in, and concepts that will help the student improve higher-order thinking skills.

Process: It should enable the student to work intensively with open-ended tasks and support their development of highlevel thinking skills such as critical, creative, problem solving and decision making, scientific thinking and research skills, communication skills, and independent and self-controlled study skills. The basic skills in the process dimension of the Grid Model attach importance to the development of skills parallel to the science process skills of the Science course (Kaplan, 2009). At this point, within the scope of the science curriculum, the Grid Model can offer students the opportunity to experience scientific process skills so that they can feel and act like a scientist.

Product: Students should have results and achievements in their learning to communicate verbally or in writing and improve by using their communication skills. (VanTasselBaska, 2002).

After determining the content, process and product dimensions within the scope of the specified theme in the Grid Model activities suitable for the ten dimensions in the Grid Model are carried out. The activities to be carried out for these dimensions should have the features listed in Tablel below.

When the Grid Model in Table 1 is analyzed in terms of dimensions, components and skills, it overlaps with the characteristics of the science curriculum and the needs of gifted and talented students. However, practical activities are needed to meet the needs of gifted and talented students in science lessons. In addition, teachers need to apply differentiation and enrichment in accordance with the model together with the components of a model in the education of gifted and talented students. Differentiation is defined as differentiating the content, process and product dimensions of the teaching based on the individual differences of the students for the same acquisitions, and allowing the themes presented in the teaching environment to suit all students with different styles, different learning approaches and different readiness levels. In other words, differentiation helps students to study content in several ways, including making sense of information, analyzing it, and creating products. In this way, it is tried to ensure that all students learn the subject and concepts effectively by going through different ways. Enrichment is characterized as

Table 1: Grid Model Steps

\begin{tabular}{|c|c|}
\hline \multicolumn{2}{|r|}{ GRID MODEL } \\
\hline Theme & The main framework in which differentiated teaching practice will take place \\
\hline The Language of Discipline & The main concepts students should learn within the scope of the theme \\
\hline Details & $\begin{array}{l}\text { Concepts that students should associate with the key concepts they need to understand, that they } \\
\text { are interested in, and that will result in in-depth learning within the theme's framework }\end{array}$ \\
\hline Unanswered Questions & $\begin{array}{l}\text { Within the scope of the theme, fundamental questions that will provide students with thinking skills } \\
\text { and that need to be answered }\end{array}$ \\
\hline Ethics & $\begin{array}{l}\text { The activity to be carried out to internalize the concept of "Ethics," which forms the basis of scientific } \\
\text { thinking skills }\end{array}$ \\
\hline Big Idea & $\begin{array}{l}\text { Within the theme's reach, students are supposed to develop a big creative idea to solve a real-life } \\
\text { problem. }\end{array}$ \\
\hline $\begin{array}{l}\text { Looking to the Future from } \\
\text { the Past }\end{array}$ & Associating studies on the subject with the past, present, and future to evaluate them holistically \\
\hline Different perspectives & Creating creative and original products for the theme \\
\hline Interdisciplinary Association & Activities to associate the theme with other disciplines \\
\hline Trends /Tendencies & Activities to reveal the current situation regarding the theme \\
\hline
\end{tabular}


the improvement of the content of the curriculum's themes according to the needs of the students and the maximization of the curriculum's established achievements. Enrichment is also defined as the study of a gifted student on a subject area in the program by deepening and expanding more than their peers. In other words, with enrichment, the scope of the curriculum is expanded and advanced topics are included. Students who attain highlevels of achievement through enrichment are more likely to develop high-level mental skills such as creativity, criticalthinking, and Scientific thinking.

In this study, it is aimed to determine the effects of science lesson activities prepared in accordance with the components and steps of the Grid model on the creative thinking skills, problem solving skills and attitudes of gifted and talented students. On the other hand, this research aims to guide gifted students' differentiation and enrichment activities performed in school. In this study, answers to the following research questions were sought.

\section{Research Questions}

1. Is there a significant difference between the Torrance Creative Thinking Test scores of the students in the experimental group in which the science lesson activities prepared in accordance with the components and steps of the grid model were applied and the control group students who were applied the support education program?

2. Is there a significant difference between the problem solving inventory scores of the students in the experimental group in which the science lesson activities prepared in accordance with the components and steps of the grid model were applied and the students in the control group who were applied the supportive education program?

3. Is there a significant difference between the scores of the Attitude Scale Towards the Science Course of the students in the experimental group, in which the science lesson activities prepared in accordance with the components and steps of the grid model were applied, and the control group students who were applied the supportive education program?

\section{Method}

\section{Research Model}

In this research, quasi-experimental model was used. Since it is not possible to select the students, who make up the experimental group of the study, independently due to limitations such as time, place and educational process, this study was conducted in the form of a quasi-experimental design (Büyüköztürk et al., 2018). In the study, an experimental design with pre-test and post-test control groups was used to examine the effect of science lesson activities prepared in accordance with the components and steps of the grid model on the creative thinking skills, problem solving skills and attitudes of gifted students. The dependent variable in the study was students' creative thinking skills, problem solving skills, and attitudes towards science, and the independent variable was science lesson activities prepared in accordance with the components and steps of the grid model.

\section{Study Group}

The study group consisted of 44 students (23 in the experimental group, 21 in the control group) in the 9-10 age group, who were identified as gifted students and who attend the same Science and Art Center support education program in Istanbul. The study group of the research was chosen by the simple random sampling method. This method is the method in which each item selected in the sampling has the same chance statistically and is completely randomly selected (Büyüköztürk, Çakmak, Akgün, Karadeniz, \& Demirel, 2014).

While there are 11 female and 12 male students in the experimental group, there are 10 female and 11 male students in the control group. In the experimental group, 13 students attend public school while 10 students attend private school. However, 12 of the students in the control group attend public school while 9 of them attend private school. All of the students were diagnosed as gifted and gifted in the general mental field.

As a result of the independent sample $t$ test conducted according to the problem solving inventory pretest data for children at primary education level before the application, it was found that there was no statistically significant difference between the experimental (X囚experiment $=85.23)$ and control $(\mathrm{X} \rrbracket$ control $=86.42)$ groups $(\mathrm{t}(0.48)=\mathrm{P}>0.54)$. As a result of the independent sample $t$ test conducted according to the Attitude Scale towards Science Course pre-test data conducted before the application, it was observed that there was no statistically significant difference between the experimental $(\mathrm{X}$ experiment $=38.24)$ and control $(\mathrm{X} \otimes$ control $=37.63)$ groups $(\mathrm{t}(0.26)=\mathrm{P}>0.61)$. As a result of the independent sample $\mathrm{t}$ test conducted according to the Torrance Creative Thinking Test pretest data before the application, it was seen that there was no statistically significant difference between the fluency, originality, elaboration and detail (abstractness of the titles, resistance to closure, creative power control) scores of the experiment and control groups

\section{Data Collection Tools}

\section{Torrance Creative Thinking Test}

In this study, Figural Form A of the Torrance creative thinking test developed by Torrance (1966) and Turkish language equivalence by Aslan (2001) was used to determine the students' creativity skills in the experimental and control group. Figural Form A consists of three activities: picture creation, picture completion and parallel lines. Torrance Test scores are calculated on the sub-dimensions of creativity: fluency, authenticity, detailing and elaboration (abstraction of 
titles, resistance to closure, control States of creative power). When calculating scoring, these four sub-dimensions are calculated separately and as total points. Three experts were involved in the scoring process. Agreement between scorers was tested with the Kendal W Fit Test.

\section{Problem-solving inventory for primary school children}

The "Problem Solving Inventory for Primary Education Children" created by Serin, Bulut Serin, and Sayg 1 (2010) has been used to collect data on problem-solving skills, one of the dependent variables. There are 24 items in the inventory consisting of three factors. Three factors in the inventory were Confidence in Problem Solving Skills, Self-Control and Avoidance, respectively. The Cronbach alpha reliability coefficient of the inventory was determined as 0,80 . Since the first-factor items express self-confidence, not giving up, and determination when facing problems, it was named "Confidence in Problem Solving Skills." The second element was called "Self-Control" because the elements include expressions about self-management, more autonomous actions, forming thoughts, and the supremacy of internally controlled features. This factor is called "Avoidance" since the statements in the third and final factor have meanings related to procrastination, ignoring, failure to face the problem, and the desire to avoid the real problem rather than addressing it.

\section{Attitude Towards Science Lesson Scale}

In this research, the "Attitude Towards Science Lesson Scale" developed by Kenar and Balc1 (2012) was used. The scale used consists of 5-Point Likert Type 12 items and three sub-factors. The first factor of the scale has six items, the second factor has three items, and the third factor also has three items. The first factor's items reflect students' anxiety, dissatisfaction, unwillingness, and ignorance of the Science course, while the second factor's items reflect students' feelings while learning and discussing science subjects. The third factor's items can be said to represent the time students spend studying Science and their attitudes toward the benefits of that time. The reliability coefficient (Cronbach alpha) value of the scale was found as $\alpha=0.83$.

\section{Data Analysis}

In the research, in order to decide on the parametric / nonparametric tests to be used to understand whether the science lesson activities prepared in accordance with the components and steps of the grid model are effective or not, the experimental and control groups' pretest and posttest scores are calculated before the experimental process and whether their score distributions meet the assumptions of normality and homogeneity. tested. For this purpose, the skewness and kurtosis values of the total scores of the pretest, posttest and permanence test obtained for each group were examined in order to determine whether the assumption of normality was achieved. It is accepted that the distribution of the scores is normal if these coefficients are between -2 and +2 (Hair, Black, Babin, Anderson ve Tatham, 2010). Levene test was conducted to test the assumption of homogeneity. As a result of the test, it has been accepted that the significance scores are higher than 0.05 , that is, in the case that there is no significant difference between the variances of the scores, the variances provide the assumption of homogeneity. Therefore, independent groups t-Test was used to test the significance of the difference between the mean scores of the pre-test-post-test scores of the two groups.

Validity and Reliability: In the study, two equal groups were selected to ensure that the scores obtained from the students in the experimental and control groups were qualified and comparable, and the study group was not biased. It was ensured that the number of participants in both groups was close to each other. Considering the maturation effect, the application is limited to 12 weeks. During the application, there was no loss of subjects that would hinder the weekly practices.

The Torrance Creativity Thinking Test of the students in the experimental and control groups was scored according to the criteria by the researcher and two different experts

Table 2: Content, process and products differentiated following the Grid Model

\begin{tabular}{|c|c|c|c|c|}
\hline \multicolumn{5}{|c|}{ THEME - CHANGE } \\
\hline Content & & Processes & & Products \\
\hline Theme Disciplines & Thinking Skills & Research Skills & Fundamental Skills & \\
\hline $\begin{array}{l}\text { Light Pollution } \\
\text { Types }\end{array}$ & $\begin{array}{l}\text { Critical Thinking and } \\
\text { Problem Solving }\end{array}$ & Using the recording system & $\begin{array}{l}\text { Determining the } \\
\text { fundamental idea }\end{array}$ & $\begin{array}{l}\text { Developing a verbal } \\
\text { presentation }\end{array}$ \\
\hline Causes of Light Pollution & Creative Thinking & Taking notes & $\begin{array}{l}\text { Expressing thoughts in } \\
\text { written form }\end{array}$ & Showing with graphics \\
\hline $\begin{array}{l}\text { Technology and light } \\
\text { pollution effects }\end{array}$ & $\begin{array}{l}\text { Using Evidence and } \\
\text { Problem Solving }\end{array}$ & Observation & Ranking & $\begin{array}{l}\text { Writing a poster, slogan, } \\
\text { newspaper article }\end{array}$ \\
\hline $\begin{array}{l}\text { The World of Living Beings } \\
\text { and Light Pollution }\end{array}$ & Problem Solving & $\begin{array}{l}\text { Using newspapers and } \\
\text { magazines }\end{array}$ & Classification & Debate \\
\hline $\begin{array}{l}\text { The Concept of Patent } \\
\text { The Concept of Chronology }\end{array}$ & $\begin{array}{l}\text { Problem Solving } \\
\text { Decision-Making }\end{array}$ & $\begin{array}{l}\text { Searching for information } \\
\text { on the internet }\end{array}$ & $\begin{array}{l}\text { Expressing thoughts } \\
\text { verbally }\end{array}$ & Self-assessment \\
\hline
\end{tabular}


before and after the application. The Kendall W test was used to determine the level of agreement between three different raters. According to these results, it is seen that the reliability between raters is high (Kendall W coefficient of harmony: 1st evaluation:, 938 - 2nd evaluation:, 924).

\section{Setting}

BİLSEM was established under the General Directorate of Special Education and Guidance Services of the Ministry of
National Education for the purpose of education of specially talented children in the field of science and art. In these centers, which are independent educational institutions, studies are carried out to ensure that gifted students of primary, secondary and secondary school age receive education in accordance with their ability areas (MEB, 2016). Basically, three skill areas are used in student admission to these institutions; general ability, painting, music. Students can be shown as gifted in at most two of these areas (MEB, 2015). Students who attend

Table 3: Practices and Activities Performed According to the Grid Model

APPLICATION OF THE GRILL MODEL

\begin{tabular}{ll}
\hline Theme & Change \\
\hline The Language of Discipline & Concepts that are focused throughout the unit; \\
& Light Pollution, Saving, Technological product, Lighting Tool \\
Details & Topics deepened with the main concepts \\
& Light pollution types, patenting procedure, timeline, problem-solving steps, features of a creative product, dimensions \\
& of creative thinking \\
Unanswered Questions & Examples of questions that the student will answer in the unit to improve their reasoning skills. \\
& What are the ways to solve a problem? \\
& What are the effects of light pollution on living beings? \\
& How does light pollution affect space exploration and research? \\
& What is the relationship between technology and energy production? \\
& Why isn't the sky seen as bright in big cities? \\
& What lighting tools have been used by people in the past? \\
& Imagine you designed a car. What kind of features would it have? \\
& What kind of awareness-raising plans would you make on light pollution? \\
& What are the effects of light pollution in the world and countries preventive efforts to solve this issue? \\
& Research on ethical principles within the scope of the unit \\
& Determining marketing techniques following patent principles by using the problem-solving steps of the products \\
created \\
Providing explanations for adhering to ethical principles
\end{tabular}

Big Idea Creative problem-solving thinking activities

What negative effects will technological advancements, such as the production of modern lighting devices, have on the world of living beings in the future? What are our solutions for these negative effects? Implementing and realizing the identified suggestions

Looking to the Future from Creative thinking and problem-solving activities to connect with past, present and future the Past

What are the lighting tools used by people from the past to the present? What was each vehicle's contribution to the next vehicle, as well as its features? What kind of lighting tool will be used in the future? Prepare your original designs.

Different perspectives

Interdisciplinary Association

Trends /Tendencies
Problem-solving activities to enable them to gain different perspectives on the subject What are the positive sides of using light? What feelings did the effect of light pollution on living beings evoke in you? What could be creative solutions to light pollution?

Associating activities with other lessons

Developing strategies to raise awareness of the threat of extinction

Designing original products to raise awareness about the threat of extinction

Recognizing the concept of chronology

Making original designs for lighting devices

Interpreting graphics regarding electricity usage in our country

Creating original products for light pollution

Activities to reveal the current situation regarding the theme

Analyzing the distribution of electricity consumption over time in Turkey and coming up with innovative methods for responsible consumption 
BILSEMs carry out their education in BILSEM together with their formal education schools (Keskin et al., 2013). In Science and Art Centers, there is an education process that differs from the curriculum in general education and the goals set. In these centers, there are 5 programs: Adaptation Program, Support training program, Individual Talents Awareness Program, Special Talents Developing Program and Project Production and Preparation.

\section{Application}

The "Lighting Tools" unit in the Scientific Thinking Skills module of the Science and Art Centers Support Training Program was differentiated in this study using the Grid model's measures. The program was implemented for 12 weeks in the 2018-2019 academic year. Two Curriculum Development Experts and one Assessment and Evaluation Specialist, and three primary school teachers from the Science and Art Center evaluated the program and offered feedback.

To carry out differentiation studies per the Grid Model, a theme must first be decided. The theme in this study is determined as "Change." Within the theme, content, process and products were determined following the Grid Model. Afterward, activities suitable for the ten dimensions stated in the Grid Model were prepared and implemented. Table 2 shows the differentiated content, process, and products of the science unit as per the Grid Model. In contrast, Table 3 shows the Grid Model-based applications and activities carried out within the study's scope.

Following the Scientific Thinking Skills module of the Science and Art Centers Support Training Program, activities about light pollution, saving, technological products and lighting equipment were held together with the study's control group. The activities did not involve differentiation practices or activities that required creative thinking.

\section{FINDINGS}

The creativity of the gifted students study six dimensions of fluency, originality, eloboration, abstractness of titles, resistance to prematüre closure, creative strengths in order to determine their level of pre-test and Torrance creativity test was used as a contest to determine whether there is a significant difference between the scores of the effects obtained from a $\mathrm{T}$ test was applied. The scores obtained by the students in the experimental group are presented in Table 4 and the scores obtained by the control group Students are presented in Table 5 .

As shown in Table 4, it was determined that there were significant differences between the pre - test and final test scores of the students who participated in the study from their levels of fluency, originality, eloboration, abstractness of titles, resistance to prematüre closure, creative strengths. In other words, it was concluded that the application had a positive effect on the creativity levels of the students.

As shown in Table 5, it was determined that there were no significant differences between the pre - test and final test scores of the control group students who participated in the study in their levels of fluency, originality, eloboration, abstractness of titles, resistance to premature closure, creative strengths.

The aim was to see how science lesson activities prepared according to the grid model's dimensions affected gifted students' problem-solving abilities. The experimental group students were given a t-test to see whether there was a difference in their scores from the problem-solving inventory developed for primary school students, given as a pre-test and a post-test. The data obtained from the test are shown in Table 6.

When Table 6 is examined, results showed the difference between the pretest-posttest mean scores of the students in the experimental group concerning "Confidence in the

Table 4: T test results of the scores obtained by the experimental group from Torrance creativity test

\begin{tabular}{|c|c|c|c|c|c|c|}
\hline Dimensions & & $N$ & $X$ & $S$ & $t$ & $p$ \\
\hline \multirow[t]{2}{*}{ Fluency } & Pre-test & 23 & 13.69 & 2.28 & -8.56 & 0.00 \\
\hline & Post-test & 23 & 20.04 & 2.63 & & \\
\hline \multirow[t]{2}{*}{ Originality } & Pre-test & 23 & 14.82 & 3.54 & -2.79 & 0.24 \\
\hline & Post-test & 23 & 17.03 & 3.74 & & \\
\hline \multirow[t]{2}{*}{ Elaboration } & Pre-test & 23 & 16.53 & 2.34 & -6.32 & 0.00 \\
\hline & Post-test & 23 & 22.03 & 1.52 & & \\
\hline \multirow[t]{2}{*}{ Abstractness of Titles } & Pre-test & 23 & 14.73 & 2.63 & -15.74 & 0.00 \\
\hline & Post-test & 23 & 19.46 & 1.82 & & \\
\hline \multirow[t]{2}{*}{ Resistance to prematüre closure } & Pre-test & 23 & 13.41 & 2.22 & -17.83 & 0.00 \\
\hline & Post-test & 23 & 17.32 & 1.13 & & \\
\hline \multirow[t]{2}{*}{ Creative strengths } & Pre-test & 23 & 10.89 & 1.63 & -17.63 & 0.00 \\
\hline & Post-test & 23 & 16.45 & 1.97 & & \\
\hline
\end{tabular}


Table 5: $T$ test results of the control group's scores from the Torrance creativity test

\begin{tabular}{|c|c|c|c|c|c|c|}
\hline Dimensions & & $N$ & $X$ & $S$ & $t$ & $P$ \\
\hline \multirow[t]{2}{*}{ Fluency } & Pre-test & 21 & 12.68 & 3.38 & -3.27 & 0.38 \\
\hline & Post-test & 21 & 13.87 & 4.46 & & \\
\hline \multirow[t]{2}{*}{ Originality } & Pre-test & 21 & 11.29 & 3.28 & -2.86 & 0.27 \\
\hline & Post-test & 21 & 12.47 & 3.64 & & \\
\hline \multirow[t]{2}{*}{ Elaboration } & Pre-test & 21 & 13.83 & 3.33 & -3.74 & 0.38 \\
\hline & Post-test & 21 & 14.36 & 3.67 & & \\
\hline \multirow[t]{2}{*}{ Abstractness of Titles } & Pre-test & 21 & 11.32 & 2.78 & -3.36 & 0.22 \\
\hline & Post-test & 21 & 12.46 & 3.12 & & \\
\hline \multirow[t]{2}{*}{ Resistance to premature closure } & Pre-test & 21 & 10.08 & 2.46 & -3.67 & 0.36 \\
\hline & Post-test & 21 & 11.24 & 2.24 & & \\
\hline \multirow[t]{2}{*}{ Creative strengths } & Pre-test & 21 & 10.46 & 2.16 & -3.44 & 0.19 \\
\hline & Post-test & 21 & 11.28 & 2.89 & & \\
\hline
\end{tabular}

Table 6: T-Test Results of the Experimental Group Students in the Problem Solving Inventory Designed for Primary School Children

\begin{tabular}{|c|c|c|c|c|c|c|}
\hline Sub-dimension & Score & $N$ & $X$ & $S$ & $t$ & $p$ \\
\hline \multirow[t]{2}{*}{ Confidence } & Pre-test & 23 & 41.47 & 13.68 & -2.44 & 0.02 \\
\hline & Post-test & 23 & 52.37 & 15.27 & & \\
\hline \multirow[t]{2}{*}{ Self-control } & Pre-test & 23 & 24.82 & 12.24 & -1.87 & 0.03 \\
\hline & Post-test & 23 & 32.46 & 14.86 & & \\
\hline \multirow[t]{2}{*}{ Avoidance } & Pre-test & 23 & 22.87 & 13.92 & -2.14 & 0.02 \\
\hline & Post-test & 23 & 16.14 & 11.71 & & \\
\hline \multirow[t]{2}{*}{ Total } & Pre-test & 23 & 85.23 & 10.47 & -2.83 & 0.00 \\
\hline & Post-test & 23 & 108.97 & 14.63 & & \\
\hline
\end{tabular}

problem-solving skills," "self-control" and "avoidance" subdimensions, and total scores of the students in the "Problem Solving Inventory for Primary Education Level Children" was statistically significant. $(\mathrm{p}<.05)$. Furthermore, there was an increase in the mean scores of "confidence in problemsolving skills" and "self-control" after the implementation. After the application, students' mean scores for "avoidance," which is a negative situation in problem-solving skills, decreased significantly. The problem-solving score increased significantly.

To determine the effect of the science lesson activities planned in line with the dimensions of the grid model on the problem-solving skills of gifted students, the difference between the control group students' scores that are achieved in the problem-solving inventory designed for children at the primary school level, which was applied as a pre-test and post-test, a t-test has been implemented. The data obtained from the test are shown in table 7.

When Table 7 is examined, figures suggested that the difference between the pretest-posttest mean scores of the students in the experimental group regarding the "confidence in problem-solving skills," "self-control" and "avoidance" sub- dimensions in the "Problem Solving Inventory for Primary School Education Children," and total mean scores were not statistically significant. ( $\mathrm{p}>$.05). Furthermore, there was no increase in the mean scores of "confidence in problemsolving skills" and "self-control" after the implementation. The students' mean scores of "avoidance," which is a negative situation in problem-solving skills, were not decreased significantly after the application. No increase in problemsolving total score was observed.

The objective was to evaluate the impact of science lesson activities prepared under the dimensions of the grid model on gifted students' attitudes towards Science. The t-test was used to assess the difference between the pre-test scores of students in the experimental group received before the application and the scores they received from the post-test after applying the attitude towards the science and technology lesson scale. The data obtained from the test are shown in Table 8.

When Table 8 is examined concerning the attitudes of students in the experimental group towards science and technology lesson scale, we see that the difference between the "interest," "enjoyment," and "proceeding the study" subdimension and total mean scores differed with the mean scores 
Table 7: T-Test Results of the Control Group Students in the Problem Solving Inventory Designed for Primary School Children

\begin{tabular}{|c|c|c|c|c|c|c|}
\hline Sub-dimension & Score & $N$ & $X$ & $S$ & $t$ & $p$ \\
\hline \multirow[t]{2}{*}{ Confidence } & Pre-test & 21 & 42.86 & 17.24 & $-1,132$ & 0.37 \\
\hline & Post-test & 21 & 43.92 & 18.93 & & \\
\hline \multirow[t]{2}{*}{ Self-control } & Pre-test & 21 & 23.37 & 13.53 & $-1,384$ & 0.21 \\
\hline & Post-test & 21 & 24.86 & 12.24 & & \\
\hline \multirow[t]{2}{*}{ Avoidance } & Pre-test & 21 & 18.34 & 13.48 & $-1,106$ & 0.29 \\
\hline & Post-test & 21 & 17.29 & 11.51 & & \\
\hline \multirow[t]{2}{*}{ Total } & Pre-test & 21 & 86.42 & 14.27 & $-0,987$ & 0.38 \\
\hline & Post-test & 21 & 87.51 & 11.54 & & \\
\hline
\end{tabular}

Table 8: T-Test Results of the Experimental Group Students in the Attitude Towards Science Lesson Scale

\begin{tabular}{|c|c|c|c|c|c|c|}
\hline Sub-dimension & Score & $N$ & $X$ & $S$ & $t$ & $p$ \\
\hline \multirow[t]{2}{*}{ Interest } & Pre-test & 23 & 18.49 & 4.22 & 2.47 & 0.00 \\
\hline & Post-test & 23 & 25.32 & 5.28 & & \\
\hline \multirow[t]{2}{*}{ Enjoyment } & Pre-test & 23 & 9.48 & 2.74 & 2.86 & 0.01 \\
\hline & Post-test & 23 & 13.57 & 3.96 & & \\
\hline \multirow[t]{2}{*}{ Prolonging the Study } & Pre-test & 23 & 8.94 & 2.93 & 3.34 & 0.00 \\
\hline & Post-test & 23 & 12.43 & 4.47 & & \\
\hline \multirow[t]{2}{*}{ Total } & Pre-test & 23 & 38.24 & 14.38 & 3.67 & 0.00 \\
\hline & Post-test & 23 & 53.76 & 16.23 & & \\
\hline
\end{tabular}

Table 9: T-Test Results of the Control Group Students in the Attitude Towards Science Lesson Scale

\begin{tabular}{|c|c|c|c|c|c|c|}
\hline Sub-dimension & Score & $N$ & $X$ & $S$ & $t$ & $p$ \\
\hline \multirow[t]{2}{*}{ Interest } & Pre-test & 23 & 17.74 & 3.98 & 2.67 & 0.37 \\
\hline & Post-test & 23 & 18.24 & 4.76 & & \\
\hline \multirow[t]{2}{*}{ Enjoyment } & Pre-test & 23 & 10.34 & 2.57 & 2.72 & 0.28 \\
\hline & Post-test & 23 & 11.46 & 3.42 & & \\
\hline \multirow[t]{2}{*}{ Prolonging the Study } & Pre-test & 23 & 8.43 & 2.74 & 3.19 & 0.32 \\
\hline & Post-test & 23 & 9.17 & 3.83 & & \\
\hline \multirow[t]{2}{*}{ Total } & Pre-test & 23 & 37.63 & 14.25 & 2.84 & 0.19 \\
\hline & Post-test & 23 & 39.14 & 14.96 & & \\
\hline
\end{tabular}

of pretest-posttest significantly $(\mathrm{p}<.05)$. We see that there was an increase in the mean scores of "interest," "enjoyment," and "prolonging the study" after the application. The total score of attitude towards Science was significantly increased.

To determine the effect of the science lesson activities planned in line with the dimensions of the grid model on the problem-solving skills of gifted students, the difference between the control group students' scores that are achieved in the problem-solving inventory designed for children at the primary school level, which was applied as a pre-test and posttest, a t-test has been implemented. The data obtained from the test are shown in Table 9.

When Table 9 is examined while taking into account the attitude towards science and technology lesson scale results belonging to the students in the control group, we see that the difference between the "interest," "enjoyment," and "proceeding the study" sub-dimension and total mean scores and their pretest-posttest mean scores were not statistically significant ( $p>05)$. We see that there was no increase in the mean scores of "interest," "enjoyment," and "prolonging the study" after the application. The total score of attitude towards Science was not significantly increased.

\section{Discussion}

The study revealed that the differentiated implementations of Science according to the Grid Model had a significant impact on the creative thinking and problem-solving skills and attitudes of gifted students. Within the study framework, 
considering the other Student differences according to the Grid Model, the content, process and products of the science lesson have been differentiated. Differentiated teaching models argue that students' differences should be taken into account. These models are thought to enable students to cooperate with their peers, experience a sense of belonging in the group, encounter more materials and stimuli related to the subject, and undertake tasks and responsibilities appropriate to their level of learning more effectively. Although this situation has allowed students to compete with themselves and not, it encourages each Student to achieve the high-level goals (Anderson 2007; Tomlinson, 2014). When the related literature is reviewed, the results of previous studies that the use of other differentiated teaching models such as the Grid Model in learning environments leads to the achievement of the objectives set by students are consistent with the findings of this study (Beler, 2010; Çalıkoğlu, 2014; Demir 2013; Üşenti, 2013).

In the study, it was determined that differentiated science applications according to the Grid Model improved the creative thinking skills of gifted and talented students. In accordance with the individual differences of the students, the activities implemented within the scope of the research were provided to find creative solutions for the problems they encounter in real life by using their imaginations. In addition, a learning environment based on in-class interaction and questioning was created, in which the teacher was a guide and the students freely shared their thoughts and feelings. These situations are assumed to contribute to students' creative thinking skills. Özerbaş (2011) confirms the findings of this study by asserting that teachers need to build environments in their classrooms where students enjoy and share their feelings and thoughts openly to develop their creativity. At the same time, Ersoy and Beser (2009) suggest that the introduction of activities that will encourage students in the classroom and create environments that will enable them to find alternative solutions to the challenges they face in their lives will have a positive impact on their creative thinking.

When the literature on the education of gifted students has been examined, it can be argued that these students' education should include activities aimed at improving creative, criticalthinking, problem-solving, and disciplinary performance skills (Sak, 2010; VanTassel-Baska \&Stambaugh, 2006;). In addition, the necessity of creating educational environments in which the creative thinking dimensions of fluency, flexibility, originality and elaboration are emphasized, open-ended questions are included, and students take risks and show courage in the activities are parallel to the findings of this research (Cooper, Baum, \& Neu, 2004; Meador, 2003). ; Sak, 2010; Tomlinson 2000).

From the data obtained in this study, in which science activities designed according to the Grid Model, which is one of the differentiated teaching models, were applied, it was determined that the students were effective in developing positive attitudes towards the science lesson. It is thought that the activities carried out within the scope of the application are student-centered, associating the subjects with daily life and students' interests, taking place in creative thinking activities, giving research tasks positively affect the attitudes of the students. Özdemir (2004) thought that science activities, which include high-level thinking skills and research skills, and enable students to encounter daily life problem situations related to scientific process skills, affect students> attitudes positively, in parallel with the findings of this research. When the relevant literature is examined, it has been determined that the inclusion of activities for thinking and research skills in the science course provides support for the development of students' attitudes (Akkanat, 2012; Candar, 2009; Demirci, 2007; Gould, Weeks, \& Evans, 2005; Stake \& Mares, 2001).

Studies back the idea that differentiated teaching methods allow students to engage effectively in the learning process while also increasing their motivation and attitudes. The finding of the study that students' participation in Class and their attitudes and motivations increased in classrooms where differentiated teaching methods were applied in paralel to the finding of McAdamis (2001) proposing that "teachers stated that students were more motivated and more willing to learn when differentiated teaching approach is utilized." The study is also similar to their findings and views of Anderson (2007), Beecher and Sweeny (2008), Chen (2007), Coulter and Groenke (2008), Fahey (2000), Geisler et al. (2007), Kapusnick and Hauslein (2001), Tieso (2001), Tomlinson and McTigne (2006), and Smutny (2003).

The study results revealed that differentiated science activities for the Grid Model effectively developed students' problem-solving skills. Regarding the activities implemented within the research scope, it is observed that the presence of problematic situations that students face in daily life and the students' efforts for finding creative solutions to these problems provide the internalization of the information they have learned. According to Ashman and Conway (1997), students who can internalize information can identify the problem they are faced with, ask themselves questions, and create connection between established knowledge and newly acquired information. This circumstance helps students to improve their ability to monitor their learning and problemsolving skills. Furthermore, differentiated teaching is intended to improve students' problem-solving skills by allowing them to be active, empowering them to undertake responsibilities, and perform research activities during the application process. These findings support the related literature that differentiated teaching positively affects problem-solving skills and increases success in problem-solving (Akkaş, 2014; Dreeszen, 2009; Samms, 2009). 
In this study, scientific knowledge was enriched by differentiating the lesson achievements following the Grid Model. In this context, differentiated teaching and differentiated learning environments have brought the analysis, evaluation, and creation of the achievements to the level of recall, understanding and application, and students' active participation. They have also encouraged students to take responsibility for learning and provide opportunities for students to develop their problem-solving skills, which is one of their higher-order thinking skills. This finding exhibits similarities with the study findings of Verschaffel et al. (1999) and Altun and Arslan (2006) who state that differentiated teaching practices that allow students to discover their learning paths contribute to their problem-solving success.

It has been observed that allowing the use of studentcentered techniques in the applications of differentiated teaching methods contributes positively to the success of the students, their active participation in the process, their interest in the lesson, and their motivation. In this study process, as presented in the daily plans of the research, brainstorming, discussion, internet research, drama, individual and group studies and flexible group work are among the strengths of the methods. It is thought that these practices, which differentiated teaching is introduced to students, are not often present in traditional teaching, have enabled the Method to have positive effects on students' achievement. In addition, these activities ensured that the lessons were interesting and enjoyable, and it was observed that the student's being on the move due to the duties given and responsibilities in the classroom increased the students' interest in the lesson.Despite this, it is assumed that the lack of differentiation studies for the student's interests and the absence of activities for their Scientific experiences and thinking skills are the explanation why the scores of the students in the control group did not improve significantly after the implementation process.

The limitations of this research are the application of the Grid Model was made only on the science course. The model can be differentiated for other lessons. Thus, the impact area of the Grid Model can be scientifically revealed. Along with the limitations mentioned above, the study group of this research consists of gifted students. It is thought that the implementation of the application with students with non gifted will also reveal the effect of the Grid Model. The application and evaluation of the Torrance Creativity test utilized in the research require expertise. The researcher has TorranceCreativity Test Practice Training.

\section{Suggestions}

As a result of the research, it was determined that gifted and talented students who participated in the application actively participated in the learning process and developed a positive attitude towards the lesson by enjoying the activities. In the light of these results, project-oriented curriculum creation studies that promote creative thinking can be used to address real-world problems and fulfill gifted students' educational needs. It is thought that getting students' opinions about the program applied in the study can shape the study in a positive way. Taking the opinions of the students can also give an opportunity to the students who are hesitant to express their opinions.

By differentiating the Grid Model for other lessons can contribute to the literature. Also, theGrid Model can be used in the education of gifted students by associating it with other differentiated models. In addition, teachers working with gifted and talented students can be given practical training on differentiated teaching models.

\section{References}

Akkanat, Ç. (2012). İlköğretim 7. sınıf öğrencilerinin bilimsel yaratıcılık düzeylerinin incelenmesi. Unpublished master's thesis, Gaziosmanpaşa Üniversitesi, Tokat.

Akkaş, E. (2014). Farklılaştırılmış problem çözme öğretiminin üstün zekâlı ve yetenekli öğrencilerin matematik problemlerini çözmelerine, tutumlarına ve yaratıcı düşünmelerine etkileri. Unpublished doctorate dissertation. Abant İzzet Baysal Üniversitesi, Bolu.

Altun, M., \& Arslan, Ç. (2006). İlköğretim öğrencilerinin problem çözme stratejilerini öğrenmeleri üzerine bir çalışma, Uludă̆ Üniversitesi Eğitim Fakültesi Dergisi, 19 (1), Bursa.

Anderson, K. M. (2007). Differentiating instruction to include all students. Preventing School Failure, 51(3), 49-53.

Aslan, A.E. (2001). Torrance Yaratıcı Düşünce Testi'nin Türkçe Versiyonu. Marmara Üniversitesi Atatürk Eğitim Fakültesi Eğitim Bilimleri Dergisi, 14, 19-40.

Ashman A.F, \& Conway, R. F. (1997), An introduction to cognitive education. Theory and applications. New York, NY: Routledge.

Beler, Y. (2010). Farklılaştırılmışöğretim ortamının sınıfyönetimine ve öğrencilerin akademik başarılarına etkisi .Unpublished master's thesis. Maltepe Üniversitesi, İstanbul.

Beecher, M. \& Sweeny, S. M. (2008). Closing the achievement gap with curriculum enrichment and differerentiation: one school's story. Journal of Advanced Academics, 19 (3), 502530

Büyüköztürk, Ş., Kılıç Çakmak, E., Akgün, Ö. E., Karadeniz, Ş. \& Demirel, F. (2018). Bilimsel araştırma yöntemleri. Ankara: Pegem Akademi Yayıncılık.

Biological Science Curriculum Study (2006). Why Does Inquiry Matter? Because That's What Science Is All About! Kendall/ Hunt Publıshıng Company, ABD.

Callahan, C. M. (2017). The characteristics of gifted and talented students. In Fundamentals of Gifted Education. London: Routledge.

Candar, H. (2009). Fen eğitiminde yaratıcı düşünme öğretim tekniklerinin öğrencilerin akademik başarı, tutum ve motivasyonlarına etkisi. Unpublished master's thesis, Marmara Üniversitesi, İstanbul.

Chen, Y.H. (2007). Exploring the assessment aspect of differentiated instruction: college EFL learners' perspectives on tiered 
performance tasks. Unpublished doctorate dissertation, The University of New Orleans.

Cooper, C. R., Baum, S. M., \& Neu, T. W. (2004). Developing scientific talent in students with special needs. Journal of Secondary Gifted Education, 15(4), 162-169.

Coulter, S.E. \& Groenke, S. L. (2008). A differentiated vocabulary unit for john knowles'a seperate peace. English Journal, 97 (4), 26-32

Cross, T. L. (2011). On the social and emotional lives of gifted children. Prufrock Press, Inc.

Çalıkoğlu, B. S. (2014). Üstün zekalı ve yetenekli öğrencilerde derinlik ve karmaşıklığa göre farklılaştırılmışfen öğretiminin başarı bilimsel süreç becerileri ve tutuma etkisi U n p ublis hed doctorate dissertation. İstanbul Üniversitesi, İstanbul.

Demir, S. ve Gürol, M. (2015). Farklılaştırılmışöğretim yöntemlerinin derin ve yüzeysel öğrenen öğrencilerin kalıcılık puanları üzerindeki etkisi. Pegem Eğitim ve Öğretim Dergisi, 5(2), 187206.

Demirci, C. (2007). Fen bilgisi öğretiminde yaratıcılığın erişi ve tutuma etkisi. Hacettepe Üniversitesi Eğitim Fakültesi Dergisi, $32,65-75$.

Dreeszen, J. L. (2009). The impact of differentiation on the critical thinking of gifted readers and the evolving perspective of the fifth grade classroom teacher. Unpublished doctorate dissertation, College of Education Kansas State Universiy.

Ersoy, E. ve Başer, N. 2009). İlköğretim 6. sınıf öğrencilerinin yaratıcı düşünme düzeyleri, Uluslararası Sosyal Araştırmalar Dergisi, 2(9), 128-137.

Fahey, J. (2000). Who wants to differentiate instruction? We did. Educational Leadership, 58, 70-72.

Geisler, J. L., Hessler, T., Gardner, R., \& Lovelace, T. S. (2009). Differentiated writing interventions for high-achieving urban african American elementary students. Journal of Advanced Academics, 20, 214-247.

Gould, J. C., Weeks, V., \& Evans, S. (2005). Science starts early: A program for developing talent in science. S. K. Johnsen \& J. Kendrick (Ed.), Science education for gifted students. Texas: Prufrock Press.

Hair, J., Black, W., Babin, B. ve Anderson, R. (2010). Multivariate data analysis (7th ed.). Upper Saddle River, Prentice-Hall, NJ, USA

Johnson, D. T., Boyce, L. N. ve VanTassel-Baska, J. (2013). Science curriculum review: Evaluating materials for high-ability learners. Gifted Child Quarterly, 39(1), 36-42.

Kaplan, S. N. (2009). The grid: A model to construct differentiated curriculum for the gifted. J. S. Renzulli, E. J. Gubbins, K. S. McMillen, R. D. Eckert vev C. A. Little (Ed.), Systems and Models for developing programs for the gifted and talented (235-251). Mansfield Center, CT: Creative Learning Press.

Karnes, F. A., \& Riley, T. L. (2005). Developing an early passion for science through competitions. S. K. Johnsen \& J. Kendrick (Ed.), Science education for gifted students. Texas: Prufrock Press.

Kapusnick, R.A. \& Hauslein, C.M. (2001). The silver cup of differentiated instruction. Kappa Delta Pi Record, 37 (4), 156-159

Kenar,İ. \& Balcı,M. (2012). Fen ve teknoloji dersine yönelik tutum ölçeği geliştirme: ilköğretim 4 ve 5.sınıf örneği. Dumlupınar Üniversitesi Sosyal Bilimler Dergisi, Sayı 34 - 201-210
Keskin Ö.M., Samancı Keskin, N., Aydın, S. (2013). Bilim ve sanat merkezleri: Mevcut durumları, sorunları ve çözüm önerileri. Üstün Yetenekliler Eğitimi Araştırmaları Dergisi 1(2), üstün Sayı, 78-96.

MEB Yönergesi, (2015). Bilim Ve Sanat Merkezleri Yönergesi. Özel Eğitim Rehberlik Hizmetleri Genel Müdürlüğü. Ankara

MEB Yönergesi, (2016). Bilim Ve Sanat Merkezleri Yönergesi. Özel Eğitim Rehberlik Hizmetleri Genel Müdürlüğü. Ankara

McAdamis, S. (2001). Teachers tailor their instruction to meet a variety of student needs. Journal of Staff Development, 22 (2), 1-5

Meador, K. S. (2003). Thinking creatively about science: Suggestions for primary teachers. Gifted Child Today, 26(1), 25-29.

Özerbaş, M. A. (2011) Yaratıcı Düşünme Öğrenme Ortamının Akademik Başarı ve Bilgilerin Kalıcılığa Etkisi. Gazi Eğitim Fakültesi Dergisi,31,(3) 675-705

Özdemir, M. (2004). Fen eğitiminde bilimsel süreç becerilerine dayalı laboratuvar yön- teminin akademik başarı, tutum ve kalıcılığa etkisi. Unpublished master's thesis, Zonguldak Karaelmas Üniversitesi. Zonguldak.

Reis, S. M. \& Housand, A. M. (2008). Characteristics of gifted and talented learners: Similarities and differences across domains. In F. A. Karnes \& K. R. Stephens (Ed.), Achieving excellence: Educating the gifted and talented. Upper Saddle River, NJ: Pearson Merril/ Prentice Hall.

Renzulli, J. S., Smith, L. H., White, A. J., Callahan, C. M., Hartman, R. K., \& Westberg, K. L. (2002). Scales for rating the behavioral characteristics of superior students. Technical and administration manual. Creative Learning Press, Inc., Mansfield, CT.

Robinson, A., Shore, B.M., \& Enersen, D.L. (2007). Best practices in gifted education: An evidence-based guide. Waco, TX: Prufrock Press.

Sak, U. (2010). Üstün zekaôlılar özellikleri tanılanmaları eğitimleri. Ankara: Maya Akademi.

Samms, P. (2009). When Teachers Differantiate Reading Instruction For Fifth Grade Students: Impacts On Academic Achievement, Social And Personal Development, Unpublished Doctoral Thesis. Argosy University.

Serin, O., Bulut Serin, N., \& Saygıll, G. (2010). İlköğretim düzeyindeki çocuklar için problem çözme envanteri'nin (ÇPÇE) geliştirilmesi. İlköğretim Online, 9(2), 446-458.

Smutny,J.F.(2003).Differentated instruction. Phi Delta Kappa Fastbacks, 506,7-47.

Stake, E. J., \& Mares, K. R. (2001). Science enrichment programs for gifted high school girls and boys: Predictors of program impact on science confidence and motivation. Journal of Research in Science Teaching, 38 (10), 1065-1088.

Sumida M. (2017) Science Education for Gifted Learners. In: Taber K.S., Akpan B. (eds) Science Education. New Directions in Mathematics and Science Education. Rotterdam: Sense Publishers.

Tieso, C. (2005). The effects of grouping practices and curricular adjustments on achievement. Journal fort he Education of the Gifted, 29, 60-89

Trna, J. \& Trnova, E. (2015). Experiments in the Development of Gifted Students in Science. In A. Krajna, L. Ryk, K. Sujak-Lesz (Eds.). Problemy dydaktyki fizyki. Wroclaw: Centrum Edukacji Nauczycielskiej Uniwersytetu Wroclawskiego. 
Torrance, E.P. (1996). Torrance tests of creative thinking : Norms technical manual. Personnel Press Inc.: LM.

Torrance, E. P. (2008). The Torrance Tests of Creative Thinking Norms-Technical Manual Figural (Streamlined) Forms A and B.Bensenville, IL: Scholastic Testing Service.

Tomlinson, C. A. (2000). Reconcilable differences?Stardards-based teaching and differentiation. Educational Leadership, 58(1), 6-11.

Tomlinson, C. A. (2014). The differentiated classroom. Responding to the needs of all learners (2nd ed.). Alexandria, VA: Association for Supervision \& Curriculum Development.

Tomlinson, C.A.\& McTighe,J.(2006). Integrating differentiated instruction and understanding by design. ABD: Association for Supervision and Curriculum Development.
Üşenti, Ü. A. (2013). Farklılaştırılmış Türkçe öğretim uygulamalarının üstün zekalı ve yetenekli öğrencilerdeki bilişsel beceri ve başarı durumlarına etkisi. International Journal of Social Science Research, 2(2).

VanTassel-Baska, J. (2002). Theory and research on curriculum development for gifted. K. A. Heller, F. J. Mönks, R.J. Sternberg ve R. F. Subotnik (Ed.), International hand-book of giftedness and talent. Oxford, UK: Pergamon Press.

VanTassel-Baska, J., \& Stambaugh, T. (2006). Comprehensive curriculum for gifted learners. Boston, MA: Pearson Education.

Verschaffel, L., De Corte, E., Lasure, S.,Van Vaerenbergh, G., Bogaerts, H.\& Ratinckx, E. (1999). Learning to Solve Mathematical Application Problems: A Design Experiment with Fifth Graders", Mathematical Thinking \& Learning. 1(1), 195-229 